International Journal of English Language and Literature Studies

$\operatorname{ISSN}(e): \quad 2306-0646$

$\operatorname{ISSN}(p): \quad 2306-9910$

DOI: $10.18488 /$ journal.23.2020.94.255.263

Vol. 9, No. 4, 255-263.

(C) 2020 AESS Publications. All Rights Reserved.

URL: wrww.aessweb.com

check for
updates

\title{
THE IMPACT OF BLENDED INSTRUCTIONS ON DEVELOPING JORDANIAN UNIVERSITY STUDENTS' MORPHOLOGICAL KNOWLEDGE AND READING COMPREHENSION
}

Fatima Rasheed

Al- Qeyam ${ }^{+}$

Khaled Ismail

Alnajjar ${ }^{2}$
${ }^{\prime}$ Assistant Professor of TEFL, Isra University, Jordan.

Email:fatima.al-qeyam@iu.edu.jo Tel: +962772567823

-Assistant Professor of Curriculum and Instruction/ Teacher Education and

TESOL, Isra University, Jordan.

Email:khaled.alnajjar@iu.edu.jo Tel: +962790080951
The Chec for updates

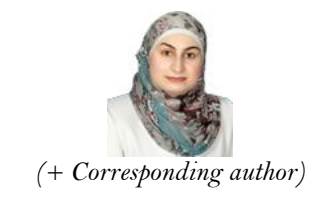

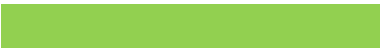

\section{Article History}

Received: 20 July 2020

Revised: 24 August 2020 Accepted: 28 September 2020 Published: 8 October 2020

\section{Keywords}

Blended learning

Morphological knowledge Reading comprehension EFL

Jordan

CALL.

\section{ABSTRACT}

This study examines the potential effects of instruction of morphology through blended methods on developing Jordanian university students' morphological knowledge and reading comprehension. A total of 50 students from two intact sections of Reading Skills course were selected. The participants were first-year university students enrolled in the second semester of the academic year 2018/2019 at a private university in Jordan. The groups were randomly divided into control and experimental; the experimental group $(n=26)$ received blended reading and morphology instruction using a special computer program called smart class; whereas the control group $(n=24)$ received traditional face-to-face instruction. For data collection, the researchers adopted a morphological test from Bataineh and Al-Kofeiri (2018) and designed a reading comprehension test. The results revealed statistically significant development of students' morphological knowledge and reading comprehension in the experimental group which could be attributed to the blended method of morphological instruction. The results of this study add new insights to the field of language teaching and research.

Contribution/ Originality: This study is one of the very few studies which have investigated the effect of integrating computer assisted language learning (CALL) with traditional learning to examine students' development of reading comprehension. The paper's primary contribution is finding that blended morphological instruction helped the students develop their morphological knowledge and reading comprehension.

\section{INTRODUCTION AND BACKGROUND}

Reading is indispensable for learners as they read for different reasons. It familiarizes learners with the topics of their specialty and enhances their knowledge about the target language. Reading comprehension has been defined as a complex but interactive process that encompasses elements, aspects and processes with the goal of eliciting meanings from a given text (Meniado, 2016). Reading has also been defined as a set of cognitive activities that involves multiple aspects like associating words with their meanings, cognitive response, and integration (Hermosa, 2002). Birsch (2011) described reading comprehension as the power of understanding a reading text; nonetheless, learners are required to have other skills to master reading. Such skills include, but are not limited to, word recognition, fluency, lexical knowledge, and previous knowledge of the target language. Reading is, however, 
an intricate process that is influenced by multiple factors, such as difficulty of the text, motivation and personal interest, and the ability to decode or recognize words (Dennis, 2008). According to Scott (2010) word knowledge, exemplified by interpreting words, spelling and vocabulary, affects reading comprehension considerably. Moreover, Torgesen (2006) believes that memory and motivation play a major part in reading comprehension as the more memory difficulties a reader faces, the greater comprehension problems he would endure. Additionally, the more motivated a reader is the better reading comprehension he would have.

Reading comprehension forms a basic building block in language learning even in first language (L1) primary education because it is the most distinctive feature of literacy. In teaching English as a foreign language, reading is also capitalized as it is considered the basic skill in language development (Martin-Chang \& Gould, 2008) more than other skills. The importance of reading as an essential skill in second or foreign language (L2) learning rises from the L2 teachers' assumption that teaching and learning the L2 depends mainly on the development of the reading skills (Hedgcock \& Farris, 2009). However, L2 learners face many obstacles in learning to read in the L2 due to several factors; one of them is the difference in the morphological systems between the L1 and the L2.

In L2 reading comprehension, it is required to make some morphological intervention especially for students in the university level who are considered as intermediate or advanced students. Those students have learnt the basic reading skills in the school level but they still need more advanced skills to enhance their reading skills. This intervention is based on the fact that the two languages have different morphological systems. Reading comprehension at this level requires the recognition of the basic building blocks of a language, viz. the words, by using various strategies including the analysis of these building blocks which involve the knowledge of what constitutes these words and this refers to morphology. Morphology requires looking at the meaning of parts of the words; and this is considered as one way of discovering the meaning of unfamiliar words (Silberstein, Clarke, \& Dobson, 2008).

Morphological knowledge works as a tool for fostering reading. If the reader is aware of inflectional and derivational morphemes for example; they have additional tools to analyze unfamiliar words and can guess the meaning in context (Hedgcock \& Farris, 2009). Most of the English words are formed by derivational processes (Nagy \& Anderson, 1984) thus, their meanings can be understood by knowing the meanings of their constituent parts.

The participants of the current study are Arab learners of English as a foreign language, so they have to learn the morphological system of English. English has its special morphological system which is extremely different from that of Arabic which makes it difficult for Arab learners of English to understand the English words easily. Morphological awareness fosters the development of vocabulary repertoire which in consequence improves reading comprehension (Nagy \& Anderson, 1984).

The twenty first century is characterized by the vast technological advancements. These advancements are reflected on the aspects of all our lives' including teaching and learning. Language teaching and learning is also affected by the technological advancement; thus new pedagogical tools have been developed (Seljan, Berger, \& Dovedan, 2004). E-learning and Blended Learning (BL) are good examples on such tools. In E-learning, learners depend totally on the learning material that is presented via computer programs and the internet. Teachers and students do not communicate and student-student communication is also missing. Thus, the combination of Elearning with traditional learning environment is evoked in new environment that includes E-learning combined with face-to-face instruction called Blended Learning (henceforth, BL).

Verkroost, Meijerink, Lintsen, and Veen (2008) define BL as mixing different teaching strategies with or without technology. In this study, the term blended learning is used to refer to mixing traditional face-to-face instruction with E-learning. According to Huang, Ma, and Zhang (2008) BL is characterized by flexibility of providing learning resources as it provides students with course information and supplementary knowledge. It may also fit various learning styles and various learners' proficiency levels by supporting individualized learning, and 
provide teachers with various means of teaching. As BL enriches the E-learning experience for both students and teachers, individualized learning is consequently enhanced. Moreover, BL makes the other teaching practices such as grading and attendance reporting easier (Akkoyunlu and Soylu, 2008). Seljan et al. (2004) assert that when Elearning is integrated with teachers' direct instruction, it suggests that teachers are deeply involved in BL and are determined to provide students with explanation and giving directions as students may lack computer skills so they need to be supervised by the teachers.

Teaching language with the aid of technology has also been the focus of research for the last couple of decades. While the purpose of BL is to increase learning outcomes and decrease the risks of teaching (Singh \& Reed, 2001) successful learning undeniably can be attained by offering learners clear and efficient instructions through real world problems to work out, and also offering ways to work out such problems.

Reading is vital for learners' success, and learners read for different reasons. For example, Salehi, Lari, and Rezanejad (2014) examined the importance of reading comprehension for university students in general and EFLs in particular, and found that reading was indispensable for passing university courses and holding a university degree. Moreover, Meniado (2016) studied the importance of reading comprehension and concluded that reading comprehension is a composite but interactive process that encompasses elements, aspects and processes with the goal of discovering meanings from a given text. Additionally, having studied the importance of reading comprehension on learners, Hermosa (2002) concluded that reading comprehension is a set of cognitive activities that involve aspects like associating words with their meanings, cognitive response, and integration.

In the study of L2 reading and E-learning, Askildson (2011) found out that E-learning, usually, is referred to as a helpful educational tool for second language reading development. Additionally, English instructors recognize the effective role computers and electronic texts play in teaching ESL/EFL.

Al-Seghayer (2016) surveyed $70 \mathrm{ESL} / \mathrm{EFL}$ instructors at diverse university sites to examine the role Elearning plays in improving L2 reading instruction in particular. The results showed that the instructors noticed the role CAR plays in enhancing the quality of L2 reading instruction and maximizing learners' reading skills.

Examples from the global literature reflect the interest in developing reading comprehension by means of morphological instruction. Zhang and Koda (2013) for instance, studied the impact of morphological awareness on developing Chinese learners' of English reading comprehension. The findings showed the importance of morphological instruction in promoting students' reading skills. Kieffer and Box (2013) also studied the effect of derivational morphology on reading comprehension for sixth -grade Spanish-speaking learners of English. This study showed the importance of morphology in fostering reading comprehension.

In the local context, Bataineh and Al-Kofeiri (2018) studied the potential effectiveness of morphological instruction on developing students' reading comprehension and concluded that morphological awareness work as a catalyst for vocabulary development and reading comprehension. Additionally, in the study of clear morphology instruction (EMI) on increasing students' EFL morphological awareness and reading comprehension, Badawi (2019) concluded that clear morphological instruction was vital for increasing EFL students' morphological awareness and reading comprehension. Smadi \& Alshara'ah, (2015) studied the effect of an instructional reading program based on the successful readers' strategies on Jordanian EFL students. The results revealed the potential effectiveness of teaching reading strategies on enhancing students' reading skill.

From the above literature it is concluded that, reading comprehension is essential for developing students' competence in L2. E-learning has proved its effectiveness as a pedagogical tool which fosters the delivery of instruction and helps students in language mastery. The study of the morphology of a language helps learners of language expand their vocabulary repertoire and in turn catalyze reading comprehension. The reading skill is built on multiple factors and word knowledge is one of them. Thus, the current study focuses on using blended learning in the instruction of morphology to develop reading comprehension. In other words, this study is based on the 
importance of teaching reading and using BL in language instruction as well as the importance of teaching morphology on developing word knowledge and enhancing the reading skill consequently.

\section{RESEARCH PROBLEM, PURPOSE, AND QUESTIONS}

Jordanian university learners of English face difficulties in learning English as a foreign language especially in the first and second year because their L1 is Arabic; a fact that is noticed by the researchers, and reported by many other English language professors in several Jordanian universities. Moreover, several local researches conducted on students' reading comprehension skill and vocabulary of English as L2 revealed Jordanian students' weakness in such areas (eg.(Al-Damiree \& Bataineh, 2015; Bataineh \& Al-Kofeiri, 2018; Smadi \& Alshara'ah, 2015)).

Many local studies addressed the issue of improving students' L2 reading comprehension using variety of techniques especially enhancing students' vocabulary knowledge (eg. (Al-Damiree \& Bataineh, 2015; Bataineh \& AlKofeiri, 2018; Smadi \& Alshara'ah, 2015)). Nonetheless, no study has examined the effect of integrating computer assisted language learning with traditional learning to monitor university students' development of L2 reading comprehension. This study aims at addressing the potential effects of computer assisted morphological instruction on developing Jordanian university students' reading comprehension, and it attempts to answer the following questions:

1. To what extent does computer assisted morphological instruction develop students' L2 morphological knowledge?

2. To what extent does computer assisted morphological instruction develop students' L2 reading comprehension?

\section{SIGNIFICANCE AND LIMITATIONS OF THE STUDY}

This study is probably the first local study which addresses the effect of instruction of morphology through blended methods on developing students' morphological knowledge and reading comprehension. The results of this study are useful to both language teachers and learners as the study offers insights to a new method in language teaching and learning.

The researchers acknowledge the potential limitations of this study due to the fact that it is limited to the sample of the study as well as one language skill (viz. reading comprehension), so generalization of the results would be improbable. Additionally, although the participants were randomly divided into experimental and control group, the classes were selected purposefully for the sake of conducting the study. In addition, the application of the treatment lasted only for one semester, so time span would be another limitation of the study. Moreover, this study is limited to the site and the participants' academic level. Although the data was collected through pre and posttests, it was confined to one university site and for one academic level (freshmen). Therefore, future research should conduct such tests at multiple sites and for different academic levels.

\section{METHODS AND PROCEDURES}

This study adopts a quasi-experimental design. Two intact reading skills courses in the academic year 2018/2019 at a private university, Jordan were selected. The students were first year majoring in English Language and literature and Translation who had studied English at school for the past twelve years. The classes were divided randomly into two groups: a control group of 24 students and an experimental group of 26 students. Equality between the two groups was ensured before they were subjected to the treatment. The results of Leven's Test Equality of Variance for the morphological test and the reading comprehension test were (0.11) and (0.58) respectively; which indicates equality between the groups of the study. To establish reliability of the tests, another group of 24 students took the exam in the class. Two weeks later they took the exam again. These students were later excluded from the main sample of the study. 
The control group was taught as per the guidelines of the course book in face-to-face classes which included instructions on reading skills and morphology as a way to understand unfamiliar words. The classes of the experimental group took the form of blended learning classes. Students in the experimental group received instruction on reading comprehension skills and morphology using face-to-face instruction in addition to a special

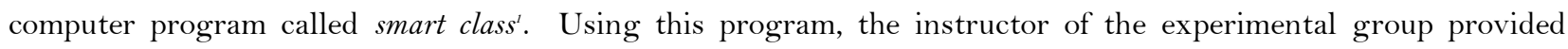
instruction and designed variety of exercises on word formation processes.

For data analysis, statistical procedures were used. Means and standard deviation of the students' scores on the pre- and post- tests, as well as the adjusted mean scores and standard errors on the post-tests were calculated. Besides, Analysis of Covariance (ANCOVA) was used to analyze students' scores.

\section{INSTRUMENTATION AND DATA COLLECTION}

For data collection, morphological awareness pre-posttests were adopted from Bataineh and Al-Kofeiri (2018) to measure students' morphological knowledge before and after the treatment, and reading comprehension preposttests were designed by the researchers to assess students' reading comprehension before and after the treatment. The morphological awareness test comprised nine questions; each of which comprised items on various morphological processes.

The reading tests included three reading passages that covered different topics, each of which consisted of five comprehension questions. The validity of the reading comprehension test was established by asking university professors of linguistics, curriculum and instruction, and applied linguistics to review the tests. The reliability of the test was established by testing- retesting a group of 24 students who were excluded from the main sample of the study. The process of testing- retesting was executed electronically using smart class. There was a two week interval between the administrations of the two tests.

\section{INSTRUCTING THE TWO GROUPS}

As stated above, the groups of the study were two intact classes of reading skills at the university level. While the first researcher taught the experimental group reading and morphology through blended methods, the control group was taught by another instructor who taught reading and morphology using face to face instruction; each of whom held a PhD in teaching English as a foreign language. Additionally, the control group received traditional face-to-face instruction via the guidelines of the textbooks Readers' Choice (Silberstein et al., 2008) and Panorama 2 (Flynn, 2006). Readers' choice included a brief illustration on the morphology of English words. This also included an explanation of some of derivational and inflectional morphemes and their meanings. It also highlighted some of the commonly used stems, prefixes and suffixes in English and their meanings and how readers could use such information in guessing the meaning of a given word in a context. Yet, this illustration was not enough for students to develop their morphological knowledge. Thus, supplementary material and additional exercises on the morphology of English were adopted from (Yule, 2010) and presented to the students.

In the experimental group, students received morphological instruction through blended methods. The class was held in a computer lab. The instruction was identical to that of the control group but it was designed to be computerized; using a special interactive computer program called smart class. In this program, the illustration of the English morphology was presented on students' screens using highlighting and coloring along with the instructor's explanation. Moreover, the additional exercises were administered to students, and feedback was given to them by means of smart class. The instructor was always there to help students and to answer their questions.

\footnotetext{
${ }^{1}$ Smart Class is a digital distance teaching platform designed specifically for language teachers. It allows them to provide students with a unique, innovative, and effective learning experience using any device, in any location, and at any time. .https://www.robotel.com/).
} 


\section{RESULTS}

The first research question required the investigation of the potential effects of computer assisted morphological instruction on developing students' morphological knowledge. For this purpose, means and standard deviation of the students' scores on the pre- and post- morphological tests, as well as the adjusted mean scores and standard errors on the post-test, were calculated as shown in Table 1.

Table-1 Means and standard deviation of the control and experimental groups on the morphological tests

\begin{tabular}{c|c|c|c|c|c|c|c}
\hline \multirow{2}{*}{ Group } & \multirow{2}{*}{$\mathbf{N}$} & \multicolumn{2}{|c|}{ PRE } & \multicolumn{2}{c|}{ Post } & \multirow{2}{*}{ Adjusted Mean } & \multirow{2}{*}{ Std. Error } \\
\cline { 3 - 7 } & & Mean & Std. Deviation & Mean & Std. Deviation & & 1.35 \\
\hline Control & 24 & 25.08 & 12.99 & 31.29 & 13.22 & 33.67 & 1.30 \\
\hline Experimental & 26 & 29.92 & 7.56 & 65.42 & 10.49 & 63.22 & \\
\hline
\end{tabular}

Table 1 shows an obvious difference in the mean and the adjusted mean scores of the control and experimental groups which seems to indicate a development in students' morphological knowledge in the experimental group. For further examination of the results, ANCOVA was used to analyze students' scores in the tests as shown in Table 2 .

Table-2. ANCOVA of the Students' Scores on the Morphological Post-test.

\begin{tabular}{c|c|c|c|c|c|c}
\hline Source & Sum of & df & Mean Squares & F & Sig. & Partial Eta Squared \\
\hline Way & 10331.73 & 1 & 10331.73 & 240.52 & $0.000^{*}$ & 0.83 \\
\hline Error & 2018.91 & 47 & 42.95 & & & \\
\hline Corrected Total & 21311.92 & 49 & & & & \\
\hline
\end{tabular}

Table 2 shows a statistically significant difference in students' scores in the morphological test (at $\alpha=0.05)$ in favor of the experimental group $(\mathrm{F}=240.52, \mathrm{df}=49 \mathrm{P}=0.000)$ which indicates that computer assisted learning developed students' morphological knowledge.

The second research question required the examination of the potential effectiveness of computer assisted morphological instruction on students' reading comprehension. The means and standard deviation of the students' pre- and post- reading comprehension tests' scores were calculated. Besides, the adjusted mean scores and the standard errors of the post-test, were also calculated for the two groups, as shown in Table 3.

Table-3 Means and standard deviation of the control and experimental groups on the reading comprehension tests.

\begin{tabular}{c|c|c|c|c|c|c|c}
\hline \multirow{2}{*}{ Group } & \multirow{2}{*}{ N } & \multicolumn{2}{|c|}{ Pre } & \multicolumn{2}{c|}{ Post } & \multirow{2}{*}{ Adjusted Mean } & \multirow{2}{*}{ Std.Error } \\
\cline { 3 - 6 } & & Mean & Std. Deviation & Mean & Std. Deviation & & 0.27 \\
\hline Control & 24 & 7.00 & 3.32 & 7.95 & 2.95 & 8.12 & 0.26 \\
\hline Experimental & 26 & 7.46 & 2.62 & 12.69 & 1.76 & 12.54 & 0.26 \\
\hline
\end{tabular}

Table 3 shows clear differences between the mean scores and standard deviations of the students' scores in the pre- and the post-reading comprehension test. Moreover, the adjusted means of the of the post-test shows differences in the scores of the reading comprehension test between the control and the experimental groups, which suggests an effect of computer assisted morphological instruction on students' reading comprehension. For further examination and comprehensive results, ANCOVA was used as shown in Table 4. 
International Journal of English Language and Literature Studies, 2020, 9(4): 255-263

Table-4. ANCOVA of the students' scores on the reading comprehension post-test.

\begin{tabular}{c|c|c|c|c|c|c}
\hline Source & Sum of Squares & Df & Mean Squares & F & Sig. & Partial Eta Squared \\
\hline Way & 242.59 & 1 & 242.59 & 135.06 & $0.000^{*}$ & 0.74 \\
\hline Error & 84.41 & 47 & 1.79 & & & \\
\hline Corrected Total & 558.18 & 49 & & & & \\
\hline Note: N=50 significant (at $\alpha=0.05)$.
\end{tabular}

Table 4 shows a statistically significant difference in students' scores in the reading comprehension test (at $\alpha=$ 0.05) in favor of the experimental group $(\mathrm{F}=135.06, \mathrm{df}=49 \mathrm{P}=0.000)$ which indicates that computer assisted morphological instruction developed students' reading comprehension.

\section{DISCUSSION, CONCLUSION AND IMPLICATIONS}

The analysis of data shows that the learners in the experimental group who underwent blended morphological instruction by means of smart class outperformed learners in the control group on the morphological test and the reading comprehension tests. These results are due to the computer assisted instruction of reading and morphology that students in the experimental group have received in the form of blended learning. Blended instruction provided learners with an interesting way for receiving the instruction. BL is a flexible and interesting way for providing students with reading instruction the morphological knowledge under focus (Huang et al., 2008). BL is flexible in terms of providing students with supplementary exercises and practice which helps in promoting students' reading comprehension and morphological knowledge.

The explicit presentation of the morphological instruction by means of smart class and by using different colors and fonts makes the affixes under focus easily noticeable. Drawing learners' attention to the affixes by explicit instruction and supporting examples makes them notice the affixes and their meanings and leads to fast and easy understanding (Schmidt, 1990). The findings reveal that Smart class helped the learners develop their morphological knowledge by allowing them to understand the various morphological processes in English which in turn developed their vocabulary knowledge as well. This shows that vocabulary knowledge is indispensable for L2 learners in promoting their reading skill, a findings consistent with a few studies (Paynter, Bodrova, \& Doty, 2005; Scott, 2010; Stanovich, 1986).

Teaching via smart class motivated the students and gave them a reason to read, and learn more about the given reading texts and the affixes they have studied; thus supported the development of their reading skill. Motivation and memory play an integral role in reading comprehension (Torgesen, 2006). The more motivated the students are, the greater reading comprehension will take place. Moreover, memory significantly affects students' reading comprehension; therefore, the more vocabulary items students memorize, the easier reading comprehension becomes.

The results of the current study agree with the results of previous studies which proved the importance of computer assisted language learning in teaching reading (e.g. (Al-Seghayer, 2016; Askildson, 2011)). They also support the results of studies that highlight the importance of morphological knowledge on developing reading comprehension (Badawi, 2019; Bataineh \& Al-Kofeiri, 2018). Additionally, the results of this study add to and support research on EFL especially when computer assisted language learning is used as a pedagogical tool. They also provide language learners and teachers with new insights for better language development. The data was collected at one university site and for one academic level (freshmen). Therefore, future research should conduct such tests at multiple sites and academic levels.

Funding: This study received no specific financial support.

Competing Interests: The authors declare that they have no competing interests.

Acknowledgement: Both authors contributed equally to the conception and design of the study. 


\section{REFERENCES}

Akkoyunlu, B., \& Soylu, M. Y. (2008). A study of students' perception in a blended learning environment based on different learning styles. Educational Technology and Society, 11(1), 183-193.

Al-Damiree, R. R., \& Bataineh, R. F. (2015). Vocabulary knowledge and syntactic awareness as potential catalysts for reading comprehension among young Jordanian EFL students. Journal of Teaching and Teacher Education, 4(01), 53-59. Available at: https://doi.org/10.12785/jtte/040106.

Al-Seghayer, K. (2016). ESL/EFL instructors' perceptions of the importance of computer-assisted reading in L2 reading instruction. Theory and Practice in Language Studies, 6(9), 1753-1761. Available at: http://dx.doi.org/10.17507/tpls.0609.05.

Askildson, L. R. (2011). A review of CALL and L2 reading: Glossing for comprehension and acquisition. International Journal of Computer-Assisted Language Learning and Teaching (IJCALLT), 1(4), 49-58.

Badawi, M. F. A. (2019). The effect of explicit english morphology instruction on efl secondary school students' morphological awareness and reading comprehension. English Language Teaching, 12(4), 166-178. Available at: https://doi.org/10.5539/elt.v12n4p166.

Bataineh, R. F., \& Al-Kofeiri, Q. M. (2018). Morphological awareness as a potential catalyst for Jordanian EFL students' reading comprehension. Lublin Studies in Modern Languages and Literature, 42(2), 66-80.

Birsch, J. R. (2011). Multisensory teaching of basic language skills. Baltimore, MD: Paul H. Brookes Publishing Company.

Dennis, D. V. (2008). Are assessment data really driving middle school reading instruction? What we can learn from one student's experience. Journal of Adolescent $\mathcal{E}^{\circ}$ Adult Literacy, 51(7), 578-587. Available at: https://doi.org/10.1598/jaal.51.7.5.

Flynn, K. (2006). Panorama 2: Building perspective through reading. Oxford: Oxford University Press.

Hedgcock, J. S., \& Farris, D. R. (2009). Teaching readers of English: Students, texts, and contexts. New York: Routledge.

Hermosa, N. (2002). The psychology of reading. Quezon City, Philippines: UP Open University.

Huang, R., Ma, D., \& Zhang, H. (2008). Towards a design theory of blended learning curriculum. In: Fong J., Kwan R., Wang F.L. (eds) Hybrid Learning and Education. ICHL 2008. Lecture Notes in Computer Science, vol 5169. Berlin, Heidelberg: Springer.

Kieffer, M. J., \& Box, C. D. (2013). Derivational morphological awareness, academic vocabulary, and reading comprehension in linguistically diverse sixth graders. Learning and Individual Differences, 24, 168-175. Available at: https://doi.org/10.1016/j.lindif.2012.12.017.

Martin-Chang, S. L., \& Gould, O. N. (2008). Revisiting print exposure: Exploring differential links to vocabulary, comprehension and reading rate. Journal of Research in Reading, 31(3), 273-284. Available at: https://doi.org/10.1111/j.14679817.2008.00371.x.

Meniado, J. C. (2016). Metacognitive reading strategies, motivation, and reading comprehension performance of saudi EFLstudents. English Language Teaching, 9(3), 117-129. Available at: http://dx.doi.org/10.5539/elt.v9n3p117.

Nagy, W. E., \& Anderson, R. C. (1984). How many words are there in printed school English? Reading Research Quarterly, 19(3), 304-330. Available at: https://doi.org/10.2307/747823.

Paynter, D. E., Bodrova, E., \& Doty, J. K. (2005). For the love of words: Vocabulary instruction that works. San Fransisco: Jossey-Bass Retrieved from: http://district.uniondaleschools.org/www/uniondaleschools/site/hosting/uniondalenyorg/grant_web/words.pdf.

[Accessed 22 July 2019].

Salehi, M., Lari, Z., \& Rezanejad, A. (2014). The effects of gender and genre on language learners' reading comprehension ability. Education Journal, 3(5), 266-271.

Schmidt, R. (1990). The role of consciousness in second language learning. Applied Linguistics, 11(2), 129-158.

Scott, R. M. (2010). What works? Research into practice a research-into-practice series produced by a partnership between the Literacy and Numeracy Secretariat and the Ontario Association of Deans of Education. What Works? Retrieved from: www.edu.gov.on.ca/eng/literacynumeracy/inspire/research/whatWorks.html. 
Seljan, S., Berger, N., \& Dovedan, Z. (2004). Computer assisted language learning (CALL). Paper presented at the Proceedings of the 27th International Convention MIPRO 2004: MEET+HGS. Rijeka: Liniavera, 2004.

Silberstein, S., Clarke, M., \& Dobson, B. (2008). Reader's choice (5th ed.). Michigan: University of Michigan.

Singh, H., \& Reed, C. (2001). A white paper: Achieving success with blended learning centra software. ASTD State of the Industry Report. American Society for Training and Development.

Smadi, S., \& Alshara'ah, M. (2015). The effect of an instructional reading program based on the successful readers' strategies on Jordanian EFL eleventh grade students' reading comprehension. Journal of Education and Practice, 6(15), 76-87.

Stanovich, K. E. (1986). Matthew effects in reading: Some consequences of individual differences in the acquisition of literacy. Reading Research Quarterly, 21, 360-406. Available at: http://dx.doi.org/10.1598/RRQ.2 1.4.1.

Torgesen, J. K. (2006). Factors that influence reading comprehension: Developmental and instructional considerations. Paper presented at the Florida State University Core Knowedge Conference. Retrieved from: http://citeseerx.ist.psu.edu/viewdoc/download;jsessionid=80509D3A4C3E71DA8C57444A7716E2C50?doi=10.1.1.365 $.3373 \&$ rep=rep $1 \&$ type=pdf. [Accessed 1 January 2020].

Verkroost, M., Meijerink, L., Lintsen, H., \& Veen, W. (2008). Finding a balance in dimensions of blended learning. International Journal on E-Learning, 7(3), 499-522.

Yule, G. (2010). The study of language. Cambridge: Cambridge University Press.

Zhang, D., \& Koda, K. (2013). Morphological awareness and reading comprehension in a foreign language: A study of young Chinese EFL learners. System, 41, 901-913. Available at: 10.1016/j.system.2013.09.009. 